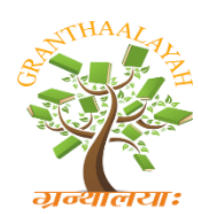

\author{
INTERNATIONAL JOURNAL OF RE
GRANTHAALAYAH \\ A knowledge Repository
}

Science

\title{
TRANSPORT AND FATE OF SELECTED HEAVY METALS IN CIRCUM- NEUTRAL RIVER ENVIRONMENT: A CASE STUDY OF THE RIVER NENT CUMBRIA, ENGLAND
}

\author{
K.U. Emerson ${ }^{1}$, E.S.Bejor ${ }^{2}$, E.E.Ekeng ${ }^{* 3}$, N.M. Ogarekpe ${ }^{4}$, A.U.Onuruka ${ }^{5}$ \\ ${ }^{1}$ Civil Engineering and Geosciences, Newcastle University, United Kingdom \\ 2, *3, 4 Department of Civil Engineering, Cross River University of Technology, Calabar, Nigeria \\ ${ }^{5}$ Department of Bioenvironmental Engineering, Imo State Polytechnic, Ohaji.Owerri, Nigeria
}

DOI: https://doi.org/10.29121/granthaalayah.v5.i6.2017.2010

\begin{abstract}
The research investigates the transport and fate of heavy metal entrenchment into the River Nent from abandoned spoil waste at the former mine site. The River Nent is found to maintain a circum-neutral $\mathrm{pH}$ and contains high concentrations of dissolved zinc $(\mathrm{Zn})$ and lead $(\mathrm{Pb})$ of $0.70 \mathrm{mg} / \mathrm{l}$ and $0.08 \mathrm{mg} / \mathrm{l}$ respectively at flow rate of $34.51 / \mathrm{s}$. Relative concentration of sulphate and carbonate ions is observed to influence the river $\mathrm{pH}$. This condition has a marked effect on the concentrations of $\mathrm{Zn}$ and an insignificant effect on $\mathrm{Pb}$, copper $(\mathrm{Cu})$, cadmium $(\mathrm{Cd})$ and nickel (Ni). A leaching experiment shows that loosely-bound $\mathrm{Zn}$ minerals in spoil waste, when entrained into the river, quickly go into solution causing a sudden rise in dissolved $\mathrm{Zn}$ concentration. However, some of the dissolved $\mathrm{Zn}$ will precipitate further downstream as carbonate, thereby lowering the amount of dissolved zinc in the water column. A similar leaching test also indicates that under acidic condition of $\sim \mathrm{pH} \mathrm{5,} \mathrm{concentrations} \mathrm{of} \mathrm{dissolved}$ $\mathrm{SZn}$ and $\mathrm{Pb}$ in solution will continue to increase with zinc being about 3 times higher than $\mathrm{Pb}$. If $\mathrm{pH}$ is maintained for a long time, the concentrations of both metals continue to rise, except enough carbonate is dissolved. This condition was observed not to affect the dissolution of $\mathrm{Pb}$ minerals.
\end{abstract}

Keywords: Diffuse Sources; Spoil Waste; Heavy Metals; Leaching Test; Circum-Neutral; River Nent.

Cite This Article: K.U. Emerson, E.S.Bejor, E.E.Ekeng, N.M. Ogarekpe, and A.U.Onuruka. (2017). "TRANSPORT AND FATE OF SELECTED HEAVY METALS IN CIRCUMNEUTRAL RIVER ENVIRONMENT: A CASE STUDY OF THE RIVER NENT CUMBRIA, ENGLAND." International Journal of Research - Granthaalayah, 5(6), 159-169. https://doi.org/10.29121/granthaalayah.v5.16.2017.2010. 


\section{Introduction}

Chemical speciation is important if the nature of pollutant interaction and migration in its environment is to be understood. Under in situ geological conditions, mineral ores are largely chemically stable; but the solid phase becomes chemically activated when exposed to the atmosphere (Younger et al., 2002). Metal ions are released due to the weathering of sulphide ores containing minerals such as sphalerite $(\mathrm{ZnS})$, galena $(\mathrm{PbS})$, and arsenopyrite (FeAsS). When this happens, there are several types of reactions which can influence the migration as well as the fate of these contaminants. But in general, the contaminant metals may either remain in solution or be removed from solution in secondary phases (Lapakko, 2002). To be removed from solution, the metals may precipitate as oxides, hydroxides, or carbonates, or get adsorbed by surfaces like iron oxyhydroxides, or coprecipitate with other metals (Smith, 1999; Lapakko, 2002). For example, dissolved organic matter (humic and fulvic acids) present in waters may react with metals resulting in possible solubility, speciation and toxic changes (Lester and Birkett, 1999). Similarly, when the tailings from a pyrite mine are exposed to oxygen and water, sulphides are oxidised to sulphates which leads to the formation of sulphuric acid thereby causing a decrease in $\mathrm{pH}$ which in turn makes the metals to solubilise (Förstner and Wittmann, 1983). This condition can be represented by a series of reactions as indicated by Younger et al. (2002).

$2 \mathrm{FeS}_{2(\mathrm{~S})}+7 \mathrm{O}_{2(\mathrm{~g})}+2 \mathrm{H}^{2} \mathrm{O} \longrightarrow 2 \mathrm{Fe}^{2+}{ }_{(\mathrm{aq})}+4 \mathrm{SO}_{4}{ }^{2-}+4 \mathrm{H}^{+}{ }_{(\mathrm{aq})}$ $4 \mathrm{Fe}^{2+}{ }_{(\mathrm{aq})}+\mathrm{O}_{2(\mathrm{~g})}+4 \mathrm{H}^{+}($aq $) \quad \longrightarrow \mathrm{Fe}^{3+}{ }_{(\mathrm{aq})}+2 \mathrm{H}_{2} \mathrm{O}$

(Equation 1-2 if insufficient oxygen is present)

The Fe3+ released in Equation 2 may be hydrolysed to form ferric hydroxide (Simón et al., 2011).

$\mathrm{Fe}^{3+}{ }_{(\mathrm{aq})}+3 \mathrm{H}_{2} \mathrm{O} \longrightarrow \mathrm{Fe}(\mathrm{OH})_{3}+3 \mathrm{H}^{+}{ }_{(\mathrm{aq})}$

or may oxidise additional pyrite by the reaction:

$\mathrm{FeS}_{2(\mathrm{~S})}+14 \mathrm{Fe}^{3+}{ }_{(\mathrm{aq})}+8 \mathrm{H}_{2} \mathrm{O} \longrightarrow 15 \mathrm{Fe}^{3+}{ }_{(\mathrm{aq})}+2 \mathrm{SO}_{4}{ }_{(\mathrm{aq})}+16 \mathrm{H}^{+}{ }_{(\mathrm{aq})}$

Chemical speciation of an element determines its availability to living organisms (De Haan et al., 1993). Trace metals in natural waters can exist in different physical states such as free or complexed, associated with colloids or with particles (GUÉGUEN et al., 2004). The extent of hazard associated with the release of metals to the aquatic ecosystem is, among other things, a function of the bio amplification and bioaccumulation potential of those metals in the organisms (Younger and Wolkersdorfer, 2004). Though models have been developed to monitor metal behaviour in mine tailings (Dai and Wang, 1992) alongside their speciation and transport (Lin and Li, 1994; Lin et al., 1992), establishing a measurable link between these metals and their ecological impact on the aquatic environment remains a major challenge due to the complexities of the ecosystems and changes in environmental conditions (He et al., 2001). It is assumed that metals are bio available for microorganisms when they exist mainly as free ions and in labile form, whereas the particle-bound or ligand-complexed metals are seen as not directly available for microorganisms (Campbell, 1995). For instance, studies of copper have shown that the toxicity of the metal does not depend on the total concentration of the metal in the aquatic environment, but on the concentration of the free ions (e.g. $\mathrm{Cu} 2+, \mathrm{CuOH}+$ and $[\mathrm{Cu} 2(\mathrm{OH}) 2] 2+)$, 
whereas the organically bound species seem to be non-toxic (He et al., 2001). Hence a leaching experiment will be conducted aimed at determining the behaviour and fate of metal contaminants particularly Zinc and Lead when spoil materials are entrained into river Nent. Toxicity of heavy metal ions have also been reported to increase when the metals combine than the toxicity of the individual element; and when calcium is present, toxicity is minimised through the formation of metal precipitate or ion competition reaction (Johnson, et al., 1994).

Zinc is a beneficial trace element for mammalian nutrition but toxic to some species of fish even at concentrations permitted in human drinking water (Förstner and Wittmann, 1983; Nuttal and Younger, 1999). Similarly, lead is a non-essential trace element (WHO, 2011), but has adverse behavioural, physiological, and biochemical effects on humans. Foet uses and children under the age of six are most vulnerable (Solomon, 2008). Until the 1970s, a blood level of 250ppb was considered safe to human blood health; but this level is no longer known to be safe for children and 50-100ppb has become the recommended guideline (WHO, 2011). Adverse biological effects for $\mathrm{Pb}$ include increased mortality, decreased benthic invertebrate abundance and diversity, and abnormal development (Environment Canada, 1998). Figure 1 shows the speciation of $\mathrm{Pb}(\mathrm{II})$ under freshwater conditions.

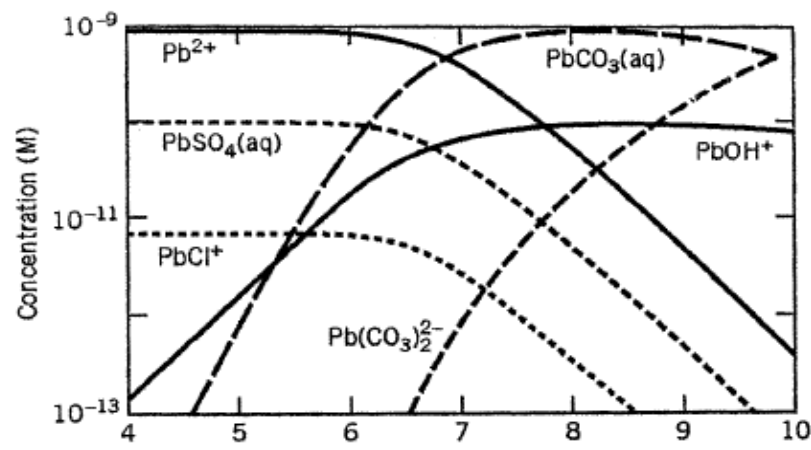

Figure 1: Speciation of $\mathrm{Pb}(\mathrm{II})(10-9 \mathrm{M})$ under freshwater conditions. Total carbonate equals $2 \mathrm{x}$ $10^{-3}$ M. (Source: Stumm and Morgan, 1996)

\section{Materials and Methods}

\subsection{Jar/ Leaching Test}

Fifty grams of the spoil waste samples in triplicate, obtained by mixing equal proportions of spoil waste from three locations at Nent head mining waste, were suspended in $200 \mathrm{ml}$ solutions of the river water, deionised water, and deionised water at $\mathrm{pH} 5$ contained in plastic bottles. The solution at $\mathrm{pH} 5$ was maintained by intermittent addition of $0.5 \mathrm{MHCl}$. Sample suspensions were placed on magnetic stirrer plates at 400rpm. Measurements of $\mathrm{pH}$ for all samples were taken immediately after setup; and water samples (filtered at $0.45 \mu \mathrm{m}$ ) were also taken in sterile plastic bottles. $\mathrm{PH}$ readings and water sampling were repeated at 1, 6, 24, 48, 72, and 96 hours sequentially for all suspensions. A drop of concentrated HNO3 was added to each of the collected water samples to bring the $\mathrm{pH}$ to $<2$. After each test, the $\mathrm{pH}$ probe (standardised with pH 4 and 7 buffers) was rinsed with deionised water to eliminate the influence of one test on the other. Samples were analysed for dissolved metals using the Varian-Vista-MPX model of the inductively coupled plasma-optical emission spectrometer (ICP-OES) following the method described in section 2.2. 


\section{Anion Analysis}

Anion analysis was performed for chloride (Cl-1) and sulphate (SO42-) anions using IC-Dionex DX320 ion chromatography. The sample was drawn using a $1 \mathrm{ml}$ syringe (flushed three times with the water sample) and injected into the ion chromatograph through a $0.45 \mu \mathrm{m}$ filter.

\subsection{Cation Analysis}

A Varian-Vista-MPX model of the inductively coupled plasma-optical emission spectrometer (ICP-OES) was used to determine the concentrations of metals of interest in each of the analysed samples. The machine uses the principle that when plasma energy is supplied to an analysis solution, the atoms are excited to a higher energy level and, upon return to a lower energy state, emit photons which are characteristics of the individual atoms. To produce the plasma, argon gas is fed to a torch coil with high frequency energy applied to the coil at the tip of the torch tube. Electromagnetic field is created in the torch tube due to the high frequency current and this causes the argon gas to ionise, thereby generating high electron density plasma with temperature in the range of $\sim 10000 \mathrm{~K}$ (SII Nanotechnology, 2011). The analysis solution is fed into the plasma through a narrow tube in the centre of the torch tube where they are vaporized, dissociated, atomized, and ionized by the energy of plasma (Falkner et al., 1995).For these analyses, several dilutions of the samples were made as the initial concentration of metals in the solutions were outside the calibrated range of the ICP machine (Calibration standards can be found in Table 1). Check and blank samples were fed after each set of analysis to ensure the machine was still working within calibrated range. Figure 2 illustrates the stages and dilutions used for the analyses.

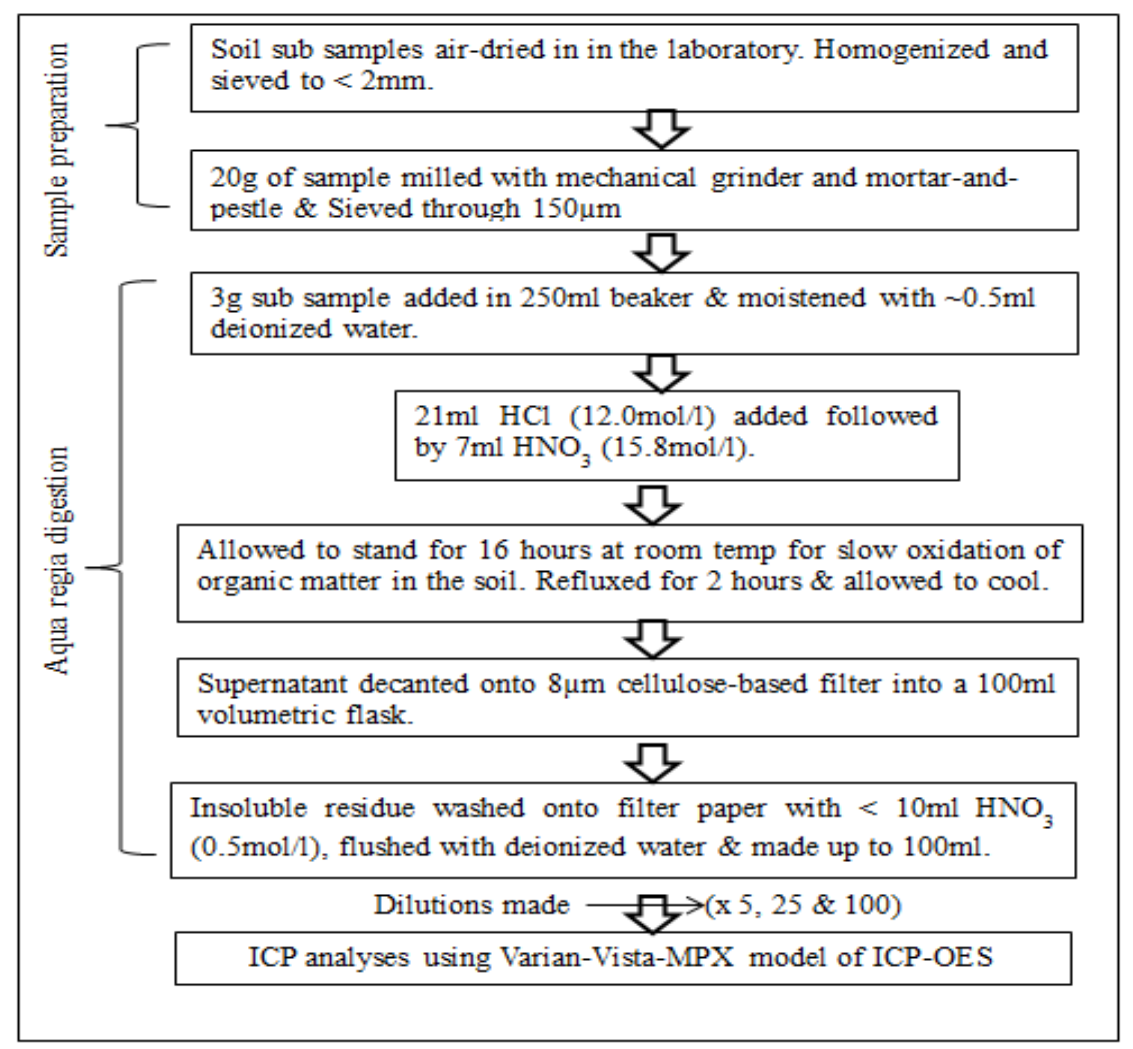

Figure 2: Flow diagram of processes for soil analysis using ICP-OES (Source: Author) 
Table 1: Calibration standards and detection limits for metals in ICP analyses

\begin{tabular}{|c|c|c|c|c|c|c|c|c|c|c|c|c|}
\hline Sample label & As & $\mathrm{Ca}$ & Cd & $\mathrm{Cu}$ & $\mathbf{F e}$ & $\mathbf{K}$ & Mg & Mn & $\mathrm{Na}$ & $\mathbf{N i}$ & $\mathbf{P b}$ & $\mathbf{Z n}$ \\
\hline $\begin{array}{c}\text { Detection } \\
\text { limit (mg/L) }\end{array}$ & $<0.05$ & $<0.02$ & $<0.01$ & $<0.01$ & $<0.01$ & $<0.01$ & $<0.02$ & $<0.01$ & $<0.01$ & $<0.01$ & $<0.05$ & $<0.01$ \\
\hline Blank $(\mathrm{mg} / \mathrm{L})$ & 0.0000 & 0.0000 & 0.0000 & 0.0000 & 0.0000 & 0.0000 & 0.0000 & 0.0000 & 0.0000 & 0.0000 & 0.0000 & 0.0000 \\
\hline $\begin{array}{c}\text { Standard } 1 \\
(\mathrm{mg} / \mathrm{L})\end{array}$ & 1.0000 & 20.0000 & 0.2000 & 1.0000 & 5.0000 & 20.0000 & 10.0000 & 0.2000 & 2.0000 & 1.0000 & 2.0000 & 2.0000 \\
\hline $\begin{array}{c}\text { Standard } 2 \\
(\mathrm{mg} / \mathrm{L})\end{array}$ & 2.0000 & 40.0000 & 0.4000 & 2.0000 & 10.0000 & 40.0000 & 20.0000 & 0.4000 & 4.0000 & 2.0000 & 4.0000 & 4.0000 \\
\hline $\begin{array}{c}\text { Standard } 3 \\
(\mathrm{mg} / \mathrm{L})\end{array}$ & 3.0000 & 60.0000 & 0.6000 & 3.0000 & 15.0000 & 60.0000 & 30.0000 & 0.6000 & 6.0000 & 3.0000 & 6.0000 & 6.0000 \\
\hline $\begin{array}{c}\text { Standard } 4 \\
(\mathrm{mg} / \mathrm{L})\end{array}$ & 4.0000 & 80.0000 & 0.8000 & 4.0000 & 20.0000 & 80.0000 & 40.0000 & 0.8000 & 8.0000 & 4.0000 & 8.0000 & 8.0000 \\
\hline $\begin{array}{c}\text { Standard } 5 \\
(\mathrm{mg} / \mathrm{L})\end{array}$ & 5.0000 & 100.0000 & 1.0000 & 5.0000 & 30.0000 & 100.0000 & 50.0000 & 1.0000 & 10.0000 & 5.0000 & 10.0000 & 10.0000 \\
\hline
\end{tabular}

\section{Results and Discussions}

\subsection{Leaching Characteristics of $\mathrm{Zn}$ and $\mathrm{Pb}$}

The leaching experiment was aimed at determining the behaviour and fate of metal contaminants, particularly $\mathrm{Zn}$ and $\mathrm{Pb}$, when spoil materials are entrained into the River Nent. It was also aimed at ascertaining changes in water quality with time upon spoil waste entrainment into the river. The results are presented in Figures 3 to 8.

\subsection{Leaching Characteristics of $\mathrm{Zn}$ and $\mathrm{Pb}$ in the River Water}

Results of Jar test showing leaching of $\mathrm{Zn}$ and $\mathrm{Pb}$ in the river water and the subsequent $\mathrm{pH}$ changes are presented in Figures 3 and 4 . The results indicate that at time $0(\mathrm{hr}$.), the $\mathrm{pH}$ of the solution was 7.51 while $\mathrm{Zn}$ and $\mathrm{Pb}$ concentrations were $0.46 \mathrm{mg} / \mathrm{l}$ and $0.03 \mathrm{mg} / \mathrm{l}$ respectively. 


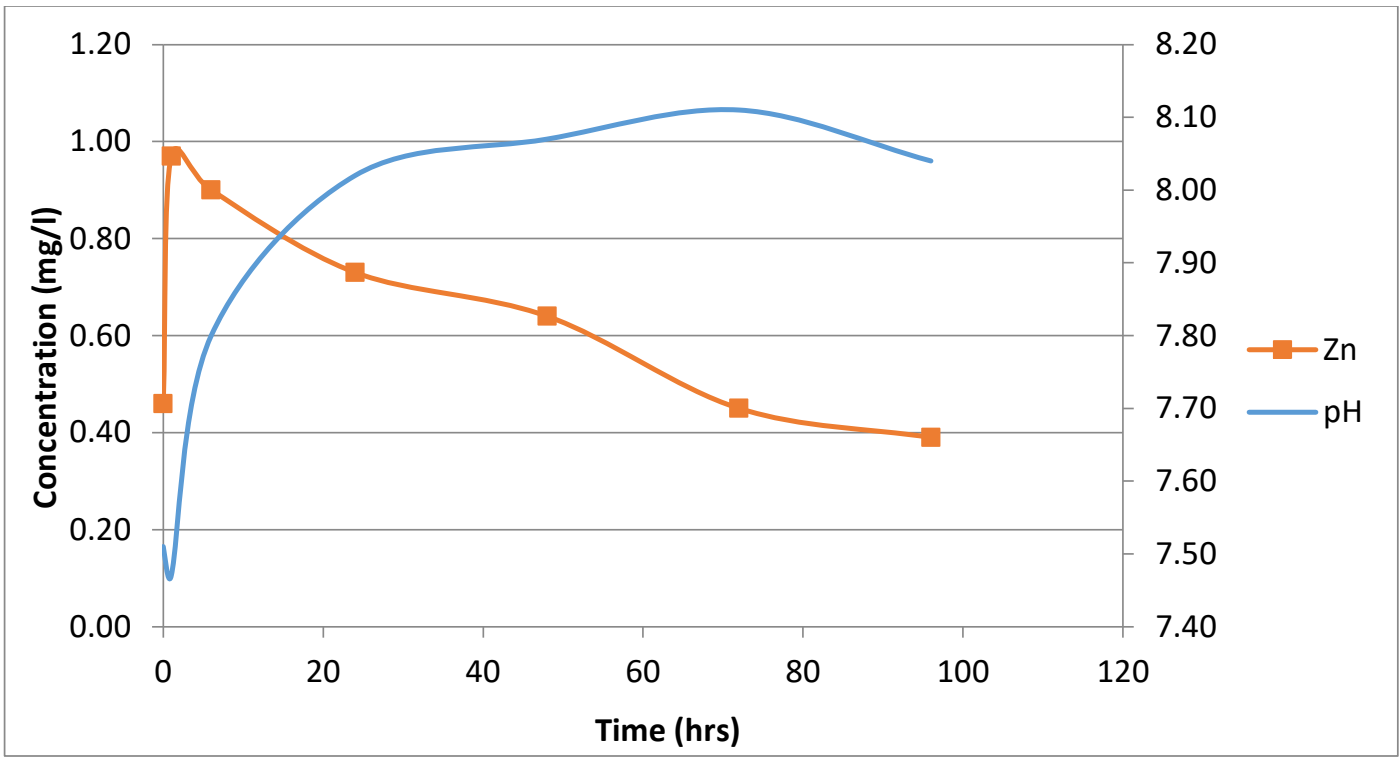

Figure 3: Leaching test showing dissolved $\mathrm{Zn}$ from spoil waste in river water as a function of time, and the resultant $\mathrm{pH}$ of solution

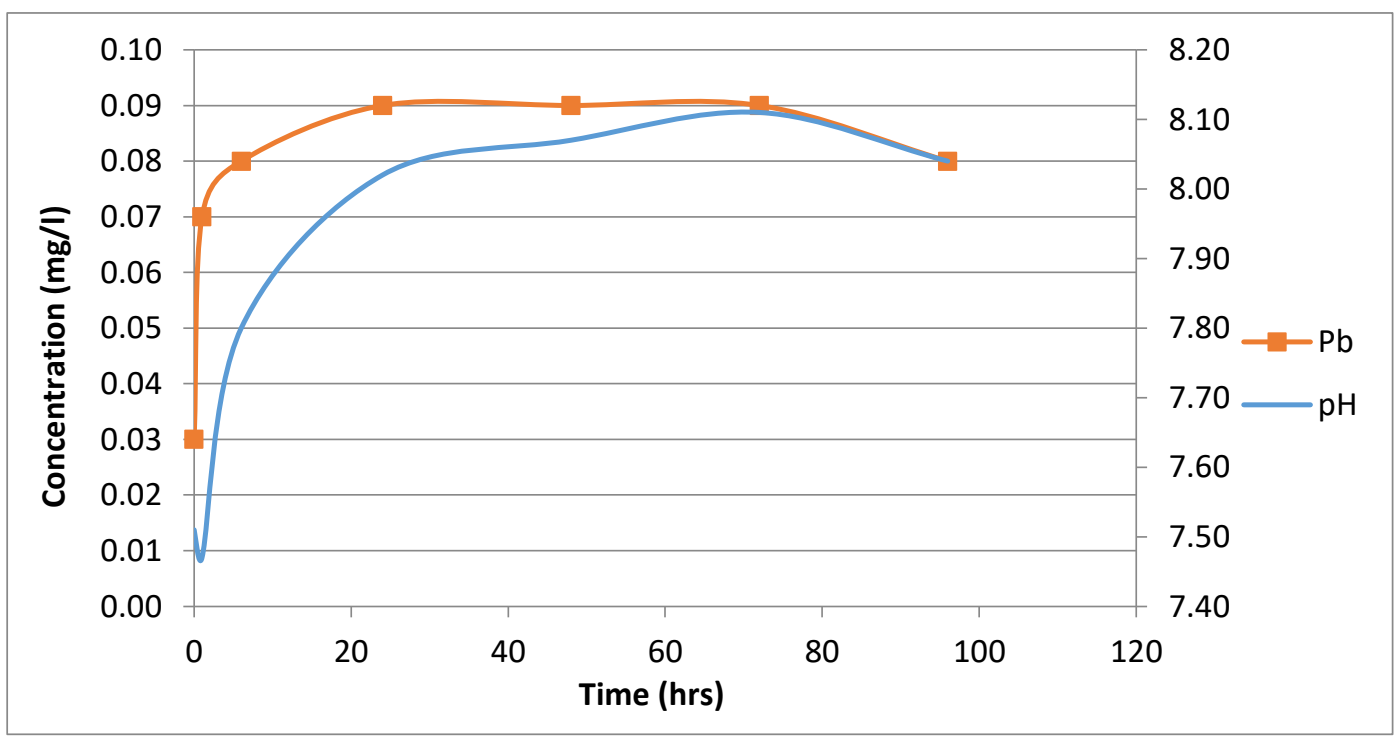

Figure 4: Leaching test showing dissolved $\mathrm{Pb}$ from spoil waste in river water as a function of time, and the resultant $\mathrm{pH}$ of solution.

However, upon addition of spoil materials to the river water, there was a sharp rise in $\mathrm{Zn}$ concentration that leached out of the spoil to the value of $0.97 \mathrm{mg} / \mathrm{l}$ and for $\mathrm{Pb}, 0.07 \mathrm{mg} / \mathrm{l}$ which was due to a rise in $\mathrm{pH}$ caused by dissolution of calcite. At time 6 hours (corresponding to a $\mathrm{pH}$ of 7.8), $\mathrm{Zn}$ concentration had declined to $0.9 \mathrm{mg} / \mathrm{l}$ and the trend continued till time 96 hours. This behaviour is similar to that reported by Stumm and Morgan (1996) who showed that concentration of $\mathrm{ZnCO} 3$, under freshwater condition, will continue to increase till $\mathrm{pH}$ of $\sim 8.0$ when it begins to decline. On the contrary, $\mathrm{Pb}$ maintained a fairly constant concentration of $0.09 \mathrm{mg} / \mathrm{l}$ but initiated a downward trend after 72 hours when the $\mathrm{pH}$ had reached a peak of 8.11 and began to decline. This implies that, in the event of spoil waste entrainment into the River Nent, some loosely bound $\mathrm{Zn}$ minerals would quickly leach out and be transported downstream 
in the dissolved form. This condition would be influenced by the dissolution of calcite from the spoil which would in turn cause a rise in $\mathrm{pH}$ of the river. The result would be a sudden rise in the amount of $\mathrm{Zn}$ that would be transported in the river within the initial hours of rainfall event. On the other hand, $\mathrm{Pb}$ would maintain a fairly constant concentration.

\subsection{Leaching Characteristics of $\mathrm{Zn}$ and $\mathrm{Pb}$ in Deionised Water at $\mathrm{pH} 5$}

Result of time dependent leaching experiment showing the concentrations of $\mathrm{Zn}$ and $\mathrm{Pb}$ leached in deionised water maintained at $\mathrm{pH}$ 5is shown in Figure 5. The result indicated that $\mathrm{Pb}$ witnessed a steady rise in the concentration from $<0.1 \mathrm{mg} / \mathrm{l}$ to $39 \mathrm{mg} / \mathrm{l}$ within the first hour of the test, and thereafter maintained a gradual increase to $350 \mathrm{mg} / \mathrm{l}$ at the $96 \mathrm{th}$ hour. There was a high correlation $(\mathrm{R} 2=0.93)$ between the amount of $\mathrm{Pb}$ in solution with time. $\mathrm{Zn}$, on the other hand, shows a sharp increase in concentration from $<0.1 \mathrm{mg} / 1$ to $\sim 350 \mathrm{mg} / 1$ within one hour of the setup and a rise of nearly equivalent proportion in the 6th hour. $\mathrm{Zn}$ maintained a less steady rise in concentration up to $1000 \mathrm{mg} / \mathrm{l}$ at the 72 hour. A closer observation of the $\mathrm{Zn}$ curve appeared as though the element was about reaching equilibrium concentration after this point despite maintaining the $\mathrm{pH}$ at 5 .

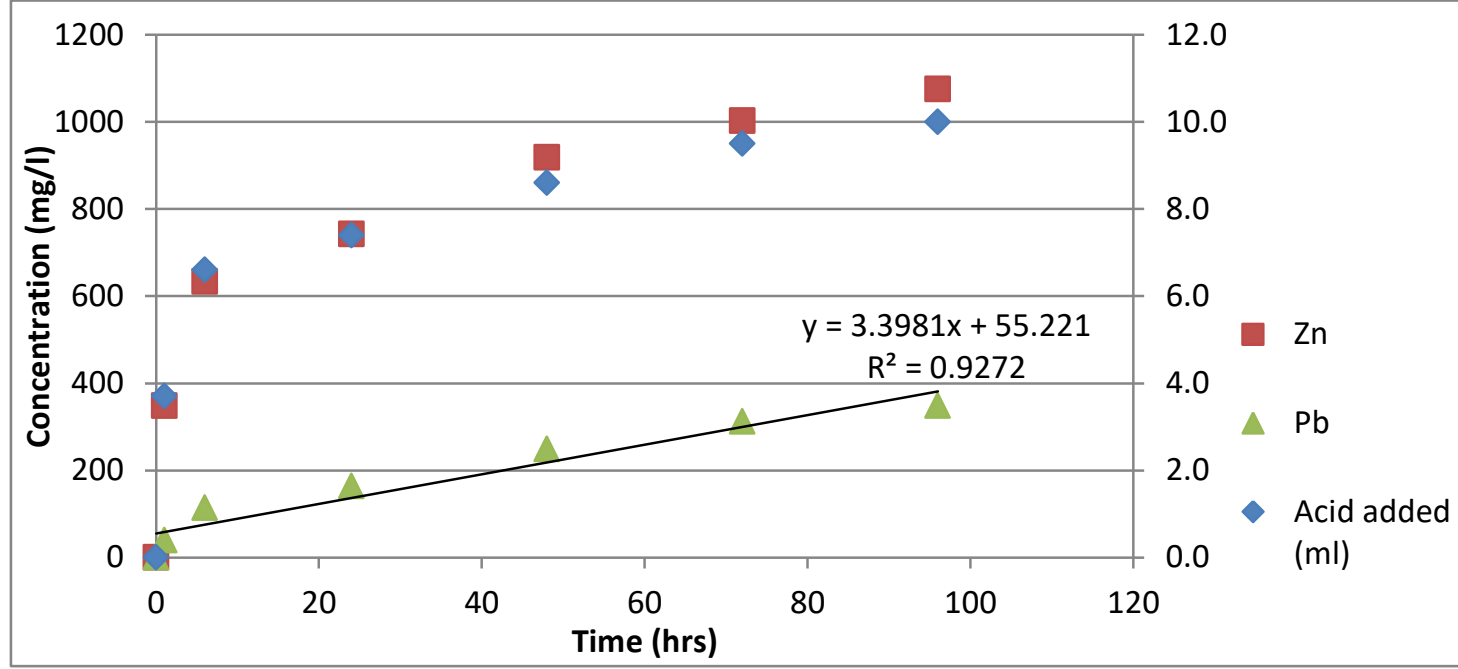

Figure 5: Leaching test showing dissolved $\mathrm{Zn}$ and $\mathrm{Pb}$ from spoil in deionised water (at $\mathrm{pH} 5$ ) as a function of time

This result is consistent with the behaviour of heavy metals in acidic solution as it is a known phenomenon that acidic solutions enhance the solubility of metals (Reddy et al., 1995). The solubility of these elements also agree with the order $\mathrm{Zn}>\mathrm{Pb}$ as reported in Martínez and Motto (1999).

\subsection{Leaching Characteristics of $\mathrm{Zn}$ and $\mathrm{Pb}$ in Deionised Water}

Figure 6 and 7 shows the leaching of $\mathrm{Zn}$ and $\mathrm{Pb}$ from spoil waste into deionised water. Analogy of both results shows that, unlike their leaching characteristics in the river water, $\mathrm{Zn}$ and $\mathrm{Pb}$ exhibit similar kinetic leaching curves which differ only by their relative concentrations in deionised water. Two peaks of 0.75 and $0.08 \mathrm{mg} / \mathrm{l}$ (at time $6 \mathrm{hrs}$ ) and 0.73 and $0.17 \mathrm{mg} / \mathrm{l}$ (at time $72 \mathrm{hrs}$ ) are prominent. A comparison of Figures 3.5 and 3.2 reveals that the amount of $\mathrm{Pb}$ leached 
in both river and deionised water for any given time was exactly the same, except for the $96 \mathrm{hrs}$ where the concentrations of $\mathrm{Pb}$ in both media differed by $20 \%$. A similar comparison of Figures 6 and 3 shows that the amount of $\mathrm{Zn}$ leached in deionised water for any given time was less than its corresponding amount in the river water (difference ranging from 8-27\%), except for its value at $72 \mathrm{hrs}$ when $\mathrm{Zn}$ concentration in deionised water was higher than its amount in the leached river water sample. This suggests that $\mathrm{Zn}$ is less soluble in deionised water than in the river water at $\mathrm{pH}$ above neutral to $\sim 8.15$, while $\mathrm{Pb}$ maintains equal solubility in both media. However, a gradual decrease in $\mathrm{Pb}$ solubility in the deionised water from $~ 28 \%$ to $13 \%$ was observed as $\mathrm{pH}$ of the solution increases from 7.47 to 8.15 , after which its solubility begins to increase. More analyses would be required to ascertain whether the changes in concentrations of $\mathrm{Pb}$ with $\mathrm{pH}$ are as a result of changes in phase/ complexation of the element. However, the leaching behaviour of $\mathrm{Zn}$ in deionised water is similar to the solubility curve of $\mathrm{ZnCO} 3$ in distilled water (Figure 8) except for its value at time 6hrs.

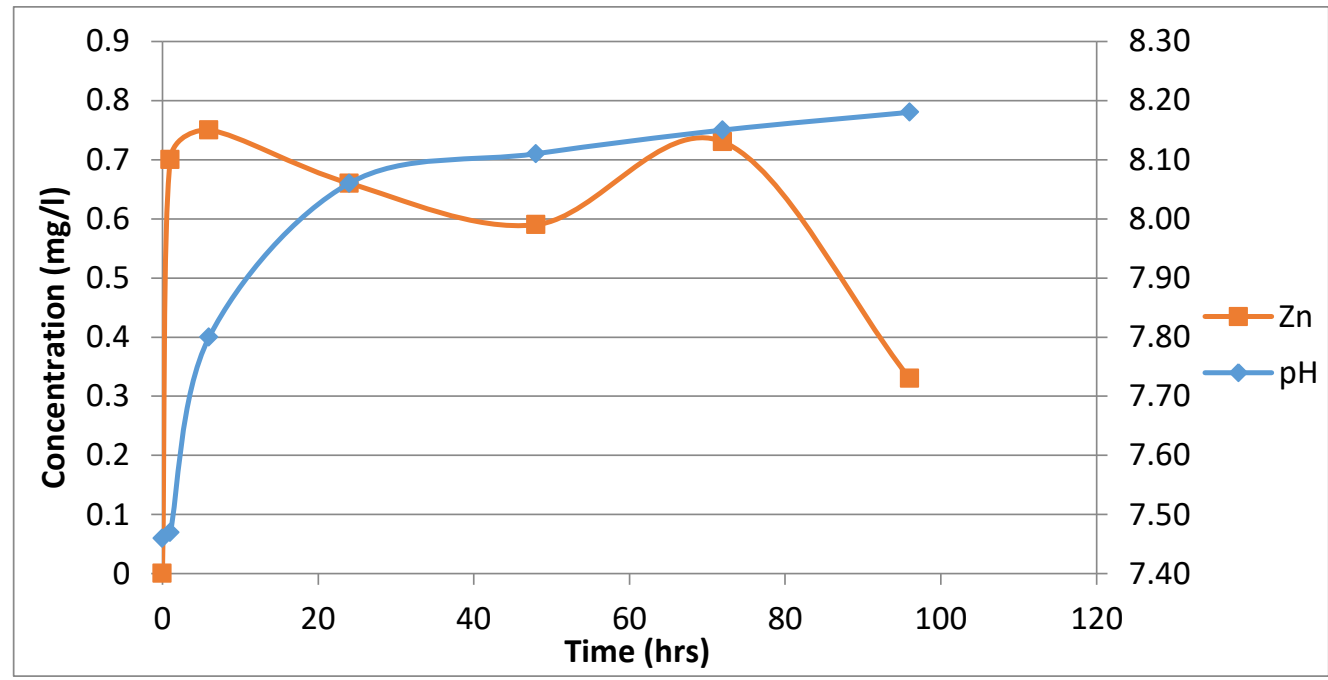

Figure 6: Leaching test showing dissolved $\mathrm{Zn}$ from spoil in deionised water as a function of time, and the resultant $\mathrm{pH}$ of solution

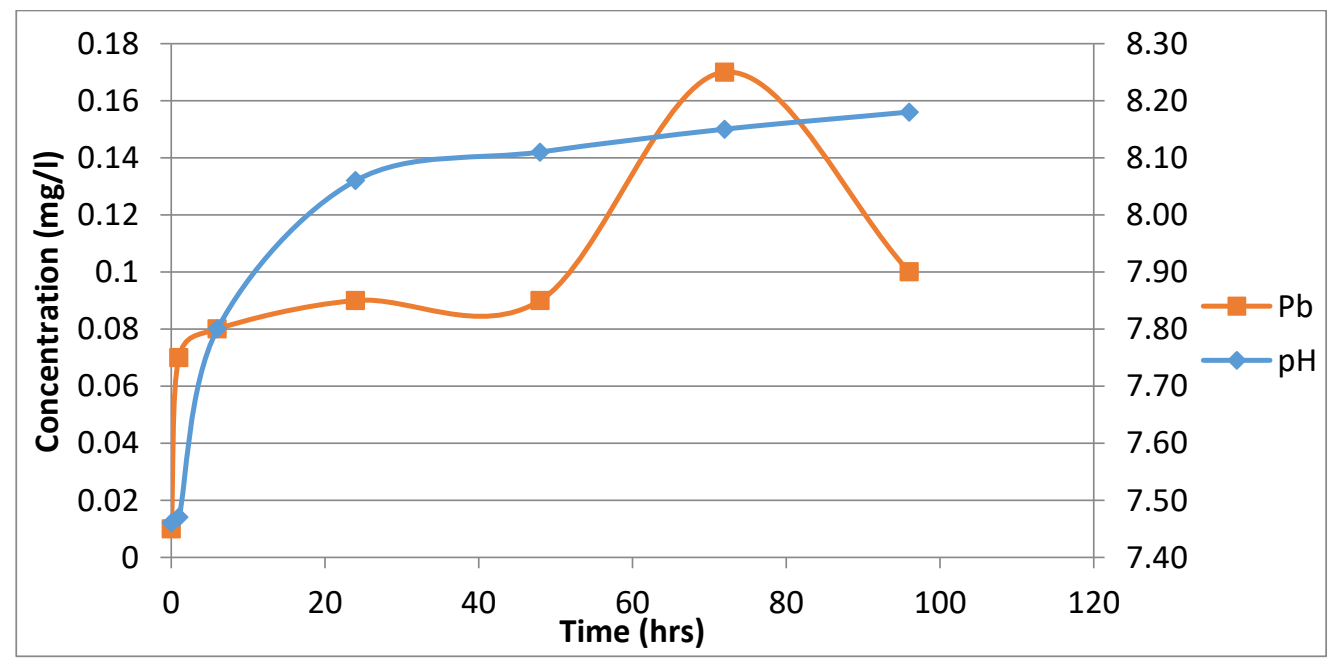

Figure 7: Leaching test showing dissolved $\mathrm{Pb}$ from spoil in deionised water as a function of time, and the resultant $\mathrm{pH}$ of solution 


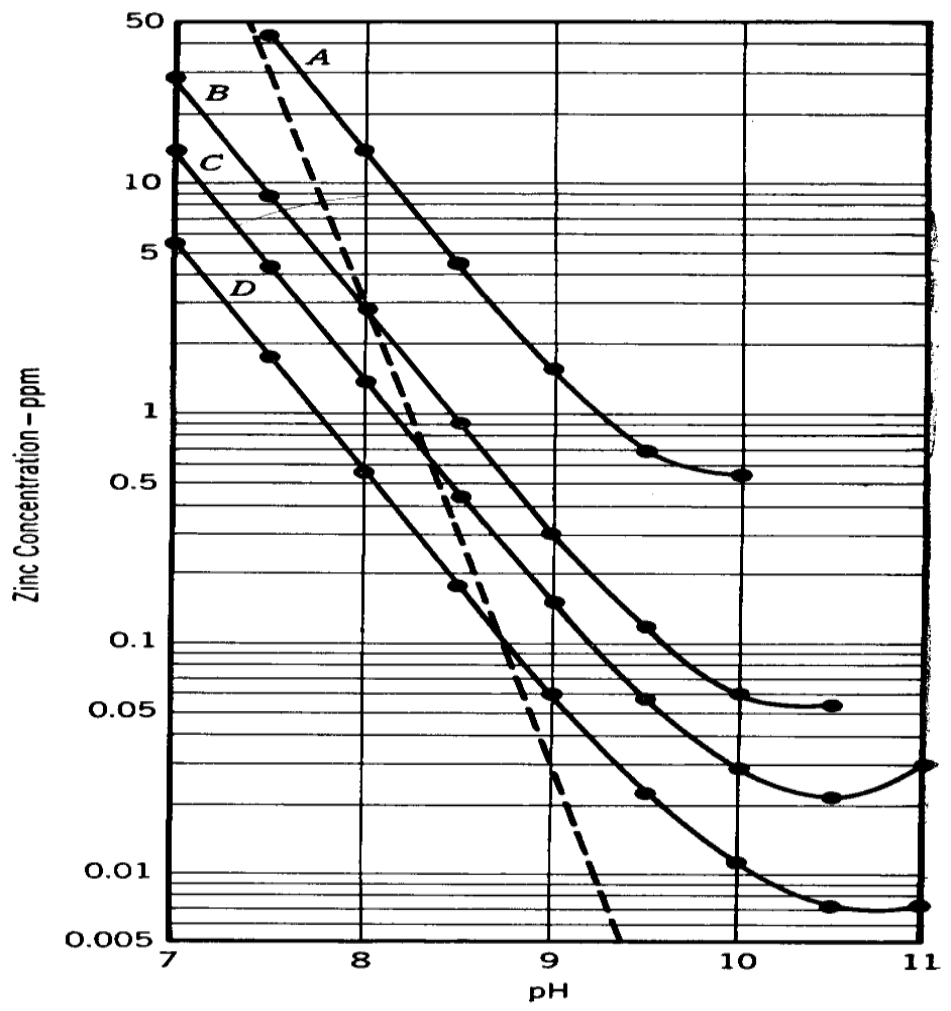

Figure 8: Solubility of zinc in distilled water as a function of $\mathrm{pH}$ and alkalinity

\section{Conclusion}

A leaching experiment shows that loosely-bound zinc minerals in spoil waste, when entrained into the circum-neutral river, quickly go into solution and are transported downstream in dissolved form, causing a sudden rise in dissolved zinc concentration. However, some of the dissolved zinc will precipitate further downstream probably as the carbonate, thereby lowering the amount of dissolved zinc in the water column. The rate at which this happens will be controlled by the alkalinity of the system at that moment. In the case of $\mathrm{Pb}$, upon entrainment into the circum-neutral river environment, it goes into solution following a slight increase in the river $\mathrm{pH}$. It remains in this dissolved form and does not likely precipitate with time. A similar leaching test also indicates that under acidic condition of $\sim \mathrm{pH} \mathrm{5}$, concentrations of dissolved zinc and $\mathrm{Pb}$ in solution will continue to increase with zinc being about 3 times higher than $\mathrm{Pb}$ which is as a result of the low solubility of zinc compared to $\mathrm{Pb}$. If this $\mathrm{pH}$ is maintained for a long time, the concentrations of both metals will continue to rise, except enough carbonate is dissolved which will, somewhat, limit the dissolution of zinc by forming a carbonate precipitate. This condition will not affect the dissolution of $\mathrm{Pb}$ minerals to the same degree.

\section{References}

[1] CAMPBELL, P.G.C., 1995. Interactions between trace metals and aquatic organisms: a critique of the free-ion activity model., In: TESSIER, A., TURNER, D.R. (eds) Metal Speciation and Bioavailability in Aquatic System, Wiley, Chichester.

[2] COULTHARD, T. J. \&MACKLIN, M. G., 2003. Modeling long-term contamination in river systems from historical metal mining., Geology, 31, 451-454. 
[3] DAI, Z. \& WANG, Z., 1992. Model for sulfide weathering in pyritic wastestone., J. Environ Sci.(China), 4(3), 29-35.

[4] DE HAAN, F.A.M., VAN RIEMSDIJK, W.H. \& VAN DER ZEE, S.E.A.T.M., 1993. General concepts of soil quality., In: EIJSACKERS, H.G.P., HAMERS, T. (eds.), Integrated Soil and Sediment Research: A Basis for Proper Protection. Kluwer Academic., Dordrecht, 155-170.

[5] DI TORO, D. M. , MAHONY, J. D., Hansen, D. J., Scott, K. J., Hicks, M. B. \& Mayr, S. M., 1990. Toxicity of cadmium in sediments: the role of acid volatile sulfide. Environ Toxicol Chem., 9, 1487-1502.

[6] ENVIRONMENT CANADA, 1998. Canadian sediment quality guidelines for lead. Supporting document. Environmental Conservation Service, Ecosystem Science Directorate, Science Policy and Environmental Quality Branch, Guidelines and Standards Division, Ottawa.

[7] FALKNER K. K., KLINKHAMMER, G. P., UNGERER, C. A., \&CHRISTIE, D. M., 1995. Inductively Coupled Plasma Mass Spectrometry in Geochemistry. Ann. Rev. Earth Planet. Sci., 23, 409-49.

[8] FÖRSTNER, U. \& WITTMANN, G.T.W., 1983. Metal pollution in the aquatic environment, Springer-Verlag, Berlin.

[9] GUÉGUEN, C., GILBIN, R., PARDOS, M., \&DOMINIK, J., 2004. Water toxicity and metal contamination assessment of a polluted river: the Upper Vistula River (Poland)., Applied Geochemistry, 19, 153-162.

[10] HE, M., WANG, Z. \& TANG H., 2001. Modeling the ecological impact of heavy metals on aquatic ecosystems: a framework for the development of an ecological model., The Science of the Total Environment, 266, 291-298.

[11] JOHNSON, M. S., COOKE, J. A. \&STEVENSON, J. K. W., 1994. Revegetation of metalliferous wastes and land after metal mining., In: HESTER, R. E. \& HARRISON, R. M. (eds) Mining and Its Environmental Impact. Issues in Environmental Science and Technology, The Royal Society of Chemistry, Letchworth.

[12] LAPAKKO, K., 2002. Metal mine rock and waste characterization tools: an overview. Minesota Department of Natural Resources, US. [Online]. Available at: http://pubs.iied.org/pdfs/G00559.pdf

[13] LESTER, J. N. \&BIRKETT, J. W., 1999. Microbiology and chemistry for environmental scientists and engineers. (2nd edition). E \&FN Spon, London.

[14] LIN, Y., LI, Q., ZHOU, G. \& SHI S., 1992. Impacts of acid mine drainage on water quality of Le An River., J. Environ Sci. (China), 4, 91-99.

[15] MARTINEZ, C. E. \&MOTTO, H. L., 1999. Solubility of lead, zinc and copper added to mineral soils., Environmental Pollution, 107(1), 153-158.

[16] NUTTALL, C. A. \&YOUNGER, P. L., 1999.Reconnaisance hydrogeological evaluation of an abandoned $\mathrm{Pb}-\mathrm{Zn}$ orefield, Nent Valley, Cumbria, UK., Proceedings of the Yorkshire Geological Society, 52(4), 395-405.

[17] O'CONNER, J. T., RENN, C. E. \& WINTNER, I., 1964. Zinc concentrations in rivers of the Chesapeake Bay region., American Water Works Association, 56 (3), 280-286.

[18] REDDY, K. J., GLOSS, S. P. \&WANG, L., 1995. Solubility and mobility of copper, zinc and lead in acidic environments., Plant and Soil, 171, 53-58.

[19] SII NANOTECHNOLOGY INC., 2011. Description of ICP Optical Emission Spectrometry (ICPOES). [Online]. Available at: http://www.siint.com/en/products/icp/tec_descriptions/descriptions1_e.html

[20] SIMÓN, M., DORRONSORO, C., ORTIZ, I.,MARTÍN, F. \&AGUILAR, J., 2011. Pollution of carbonate soils in a Mediterranean climate due to a tailings spill., Departamento de Edafología y Quimica Agrícola, Facultad de Ciencias, Universidad de Granada, 18002 Granada, Spain.

[21] SMITH, K. S., 1999. Metal sorption on mineral surfaces: An overview with examples relating to mineral deposits. 
[22] STUMM, W. \&MORGAN, J. J., 1996. Aquatic chemistry. (3rd edition), John Wiley \& Sons, Inc., New York.

[23] WHO, 2001. WORLD HEALTH ORGANISATION. Water, Sanitation and Health (WSH). [Online] Available at: http://www.who.int/water_sanitation_health/diseases/lead/en/

[24] YOUNGER, P. L. \& WOLKERSDORFER, C. (eds.), 2004. Mining Impacts on the Fresh Water Environment: Technical and Managerial Guidelines for Catchment Scale Management., Mine Water and the Environment, 23, S2-S80.

[25] YOUNGER, P. L., BANWART, S. A. \&HEDIN, R. S., 2002. Mine water hydrology, pollution, remediation. Kluwer, Academic Publishers, London.

*Corresponding author.

E-mail address: ekengemmanuel@yahoo.com 